\title{
Artists' books, czyli czym jest owoc małżeństwa książki ze sztuką
}

W dniach od 10 do 14 marca 1998 roku profesor wrocławskiej Akademii Sztuk Pięknych Eugeniusz Józefowski zorganizował w Zielonej Górze warsztaty zatytułowane „Książka Artystyczna jako obiekt oraz warsztat edukacyjny”. W ich ramach odbył się cykl ćwiczeń „Inna książka”, podczas których, między innymi, studenci mieli stworzyć oryginalne dzieła książkowe związane z ich osobistymi doświadczeniami, zakorzenione w ich biografiach, a następnie udokumentować je i zaprezentować przed resztą grupy. Pomysłowość uczestników dalece przerosła oczekiwania prowadzącego. Wśród powstałych obiektów znalazły się tak różnorodne pozycje, jak choćby praca Andrzeja Bembenka, który:

Przyniósł ze sobą wiele owoców i warzyw, a na nich całą paletę dodatków smakowych w formie przypraw, sosów i ziół. Zgromadził to obok stołu, do którego zaprosił uczestników. Zaproponował tę sytuację po to, by zrobili potrawę — stronę książki mającą w sposób smakowy i wizualny mówić jak najwięcej o osobie, która siedzi naprzeciw. [...] Natomiast ostatnia propozycja Andrzeja polegała na tym, że następowała wymiana prac do konsumpcji i każdy z uczestników miał się zastanawiać nad tym, jak jest postrzegany przez innych ${ }^{1}$.

Przemysław Gapiński z kolei skłonił różne osoby do wykonania w samotności zdjęcia wybranej przez nie części ciała. Potem, na podstawie otrzymanych fotografii, artysta przygotował dużą stronę składającą się na przyszłe dzieło. W ostatniej fazie projektu zszył wszystkie kartki w książkę, której okładkę pokrył warstwą czarnych włosów wskazujących na jej somatyczną tematykę. Równie oryginalnych pomysłów było znacznie więcej. W zasadzie każda z przygotowanych prac wyróżniała się i oddziaływała na odbiorcę w inny sposób. W podsumowaniu wszystkich dwudziestu projektów powstałych podczas warsztatów Józefowski napisał:

${ }^{1}$ E. Józefowski, Warsztat pt. „Inna książka” — w rozumieniu studentów IV roku na zajęciach w Pracowni Edukacji Twórczej, [w:] Książka artystyczna jako obiekt oraz warsztat edukacyjny, Zielona Góra 1998, s. 46. 
Tylko jeden student zrealizował obiekt plastyczny w formie tradycyjnie przeglądanej książki. Jej inność rzuca się w oczy przez monumentalny rozmiar i niepowszednie materiały użyte do jej realizacji.

Pięć osób zbudowało dokumentację powarsztatową w formie książki do przeglądania, opatrzonej komentarzem. Poczuwały się one jednak do skonstruowania ich w nietypowy sposób, pozostający w związku z zawartością merytoryczną przekazu.

Użyte media to: wideo - przez jedną osobę, działalność rysunkowa — przez dwie, działalność typowo malarska — przez jedną, działalność rysunkowo-malarska występowała zaś w sposób mieszany w kilku innych. [...]

Pojmowanie „inności” książki sprawiło, że niektóre formy są tak bardzo oddalone od ideacyjnego pierwowzoru, iż trudno niewtajemniczonym odbierać je jako książkę².

Różnorodność prac uzyskanych podczas warsztatów wskazuje z jednej strony na dużą wyobraźnię i twórczą wrażliwość biorących w nich udział studentów, z drugiej jednak ilustruje pewną trudność związaną ze współczesną recepcją pojęcia „książka”, które wydaje się znacznie pojemniejsze semantycznie, niż można by przypuszczać. Analizując jedynie dwadzieścia projektów powstałych podczas zajęć Józefowskiego, mierzymy się z próbą interpretacji każdego z dwóch dziesiątek zupełnie odmiennych wystąpień artystycznych. Wykorzystują one rozmaite materiały, mają kompletnie różne formy: przypominają rzeźby, czasem księgi, obrazy, a niekiedy nawet instalacje czy performance’y. Jednocześnie każda z prac nazywana jest w przywołanych cytatach książką, opatrzoną jedynie przymiotnikiem rodzaju żeńskiego ,artystyczna”. Co właściwie on oznacza?

Według słownikowej definicji tyle, co ,związany ze sztuką lub z artystą” lub „posiadający walory artystyczne”3. Oba te objaśnienia są kłopotliwie obszerne. W ich myśl omawianym przymiotnikiem można określić każdy efekt działalności twórczej. Ciekawą próbę zawężenia definicji wyrazu „artystyczny” podejmuje Radosław Nowakowski. Stwierdza on, że ludzkie pojmowanie sztuk pięknych przywołuje skojarzenia związane z przerabianiem mięsa. Mamy wędliny, ryby, podroby, kotlety i wszystko to powinno być uważane za mięso. W rzeczywistości jest jednak inaczej i o ile każdy z nas bez wahania do tej kategorii przyporządkuje kotlet schabowy, to w przypadku galaretki z nóżek sprawa nie będzie już tak oczywista. Podobnie, zdaniem Nowakowskiego, rzecz ma się ze sztukami wizualnymi. W ich przypadku „mięsem” będzie malarstwo, grafika czy rzeźba i to właśnie tego typu dzieła w oczach modelowego odbiorcy postrzegane będą jako artystyczne. Istotę stanowi to, że ,zwyczaje i ogólne mniemania przeciętnego i nieprzeciętnego obywatela bywają jednak zaskakujące"4 . Nowakowskiego zdziwiło, gdy pewnego dnia usłyszał przypadkiem zwrot ,piosenka artystyczna”. W muzyce nie ma

${ }^{2}$ Ibidem, s. 59.

3 Artystyczny, [hasło w:] Stownik Języka Polskiego PWN, http://sjp.pwn.pl/sjp/artystyczny;2441413 [dostęp: 6.06.2017].

${ }^{4}$ R. Nowakowski, Czy istnieje hipertekstowa ksiązka (artystyczna), Book Art Museum [strona internetowa Muzeum Książki Artystycznej w Lodzi], http://www.book.art.pl/index.php/biblioteka-ok [dostęp: 6.06.2017]. 
wszak nic wizualnego ani materialnego. Po dłuższym rozważaniu dochodzi on do wniosku, że:

[...] artystyczne miało znaczyć w tym przypadku coś odmiennego, nietypowego, rzadkiego, czego nie można usłyszeć codziennie, może nawet dziwacznego, niezrozumiałego, a już na pewno wymagającego zastanowienia się, coś raczej dla wybranych, tych, którzy przeszli jakąś inicjację (Gimnastyka artystyczna tym różni się od normalnej gimnastyki, że ma w sobie elementy baletu, balet zaś można by określić jako taniec artystyczny, a jego artystyczność w dużej mierze opiera się na jego nieużyteczności, nieprzydatności do celów towarzyskich, pomijając oczywiście rozmowy widzów w kuluarach — to też dosyć ciekawa, kolejna interpretacja artystyczności) ${ }^{5}$.

Wedle toku rozumowania Nowakowskiego analizowany przymiotnik oznacza coś odbiegającego od przyjętej normy albo nieutylitarnego, powstałego dla siebie samego. Czy zatem książkę artystyczną należałoby rozumieć, jako w jakiś sposób nieoczywistą, inną niż wszystkie kodeksy? Owa odmienność miałaby się objawiać w wyglądzie, pełnionej funkcji, możliwościach zastosowania? Mamy tu do czynienia z księgą, która weszła w sferę sztuk wizualnych, czy odwrotnie - wciągnęła je do swojej domeny? A może doszło raczej do spotkania w połowie drogi, gdzieś na granicy? Do odpowiedzi na te pytania niezbędne będzie choć krótkie spojrzenie na historię tego niespodziewanego mariażu dwóch — wydawałoby się oddzielonych od siebie na zawsze kanonicznym podziałem Lessinga — dziedzin.

Do nawiązania wspomnianej relacji niezbędne były odpowiednie okoliczności zewnętrzne, które zaszły mniej więcej w drugiej połowie XX wieku, a więc wykształcenie się postmodernizmu czy jak woli go nazywać Zygmunt Bauman — płynnej nowoczesności. Znany socjolog charakteryzuje ów okres następująco:

[...] jak wszystkie płyny nie potrafi zbyt długo trwać nieruchomo i zachowywać jednego kształtu. Wszystko lub niemal wszystko w naszym świecie zmienia się: mody, którym ulegamy i przedmioty, którym poświęcamy uwagę [...], rzeczy, o których marzymy i których się lękamy, rzeczy, których pożądamy i które budzą naszą niechęć, rzeczy, które dają nam nadzieję i które napawają nas niepokojem. Zmieniają się także warunki, w których żyjemy, pracujemy i próbujemy planować naszą przyszłość, w jakich łączymy się i rozłączamy (lub zostajemy rozłączeni) z innymi ludźmi. Okazje do pomnożenia szczęścia i groźne zapowiedzi nieszczęścia zjawiają się i znikają, nadciągają i umykają, na ogół zbyt szybko i zwinnie, abyśmy mogli w jakiś rozsądny i skuteczny sposób pokierować ich biegiem, kontrolować lub przewidywać ich ruchy ${ }^{6}$.

Transformacje, jakim ulegała i ulega nasza codzienność na płaszczyźnie społecznej i prywatnej, znajdują swoje odzwierciedlenie w kulturze, którą również określa się coraz częściej jako płynną. Obecne w niej granice, jak choćby przytaczany podział Lessinga, przestają mieć jakiekolwiek zastosowanie w praktyce. Kolejne przestrzenie działalności artystycznej dryfują gdzieś ponad nimi i przenikają się, tworząc nowe, dotąd nieznane i inspirujące jakości. Nadużywając nieco patosu, można by powiedzieć, że mury dzielące dotąd nasz świat (także artystyczny) zaczynają się rozpadać. W ich okolicach powstają nowe przestrzenie. Ten fakt

\footnotetext{
5 Ibidem.

${ }^{6}$ Z. Bauman, 44 listy ze świata plynnej nowoczesności, przeł. T. Kunz, Kraków 2011, s. 5-6.
} 
Alicja Kępińska w swojej książce pod wymownym tytułem Sztuka w kulturze płynności uważa za jedną z najważniejszych cech współczesnej działalności artystycznej:

Przestrzenie takie rozrywają dawną jedność bytu („domu”): zamieniają nasz świat na wiele światów [...]. Na ich krawędziach mnożą się między-światy, w których rozwija się nieuchronny proces zacierania dawnych binarnych opozycji, które kiedyś porządkowały nasz „świat”. [...]

W procesie owych zatarć, w toku przenikania się dawniej rozdzielonych jakości, tworzą się nowe styki, nowe intensywności, nowe trasy iskrzenia. Jest to przy tym proces ciągły, w którym żadna wyłaniająca się rzecz, czy zjawisko nie zastyga w swej formie. Nic nie chce być sobą „do samego końca" [...]

Właśnie w tych między-światach, jak często zdarza się na terenach przygranicznych, powstają nowe jakości i zjawiska czerpiące z dorobku i doświadczeń obu przestrzeni. Nie należą w pełni do żadnej z nich, są hybrydami, mieszańcami w pozytywnym tego słowa znaczeniu. Zamiast ograniczać się i wbrew sobie dopasowywać do ram tylko jednego z miejsc czy w tym kontekście dziedzin, wychodzą poza nie i próbują stworzyć coś nowego - styk, iskrzenie... świat?

Takie właśnie realia stworzyły idealną płaszczyznę pod narodziny zjawiska artist's book. To jednak nie wszystko. Należy wyraźnie podkreślić, że choć związek sztuki i książki nie powstał z przymusu, to obie te dziedziny wzajemnie się potrzebowały. Każdej z nich brakowało ożywczego impulsu, który wyrzuciłby ją z głębokich kolein, w których przez długi czas tkwiła. „Poślubiając sztukę, książka redefiniuje swoją aktualność i odnawia swojego ducha” powiada Leszek Brogowski ${ }^{8}$. Zaczyna być postrzegana jako dzieło sztuki, niezależne od literatury czy szerzej - tekstu. Akt lektury przestaje polegać wyłącznie na składaniu liter w słowa, słów w zdania, zdań w akapity... Księgę zaślubioną sztuce czyta się jako integralną całość, w której każdy element ma znaczenie dla odbioru, a samo słowo nie tylko nie jest najważniejsze, ale nawet niezbędne. Doświadcza się jej wieloma zmysłami: oczywiście wzrokiem, ale także dotykiem czy słuchem. Takie dzieło podkreśla swoją indywidualność i daje odpór uprzemysłowieniu rynku księgarskiego oraz kompletnemu zatarciu idei księgi jako wyjątkowego przedmiotu nastawionego raczej na prawdę i piękno niż zysk. Te przemiany są szczególnie istotne w obliczu transformacji, jaką obecnie przechodzi forma książki — rewolucji największej od czasów Gutenberga.

Ekspansja e-booków i innych nowoczesnych środków zapisu sprawia, że tekst stopniowo przechodzi do świata wirtualnego, a sam kodeks zostaje pozbawiony czynnika, który do tej pory go definiował. W powszechnym rozumieniu słowo „książka” było niemal równoznaczne z zapisanymi na jej kartach literami dziełami literackimi, naukowymi i innymi. Tak długo była ona nośnikiem słowa

${ }^{7}$ A. Kępińska, Sztuka w kulturze plynności, Poznań 2003, s. 6.

${ }^{8}$ L. Brogowski, L'art, le livre, meme combat, [w:] Livres imprimés et maquettes. Les Éditions Incetain Sens [katalog wystawy] przekład własny autora, s. 8, http://www.hermandevries. org/arch_catalogues/cat_2003_bn_livres.pdf [dostęp: 14.06.2017]. 
pisanego, że niemal się z nim zrosła, tracąc przy tym swoją indywidualność, coś, co moglibyśmy nazwać „książkowością”. Dopiero, gdy pojawiły się nowsze, praktyczniejsze, tańsze i funkcjonalnie lepsze formy służące zapisywaniu treści, książka zaczęła zwracać uwagę na swoją fizyczność, jako na czynnik wyróżniający ją na ich tle i dający w jakiś sposób przewagę. Tak więc zwrot w kierunku sztuki, który początkowo miał być buntem przeciwko komercjalizacji rynku księgarskiego i spowszednieniu książek, powoli staje się dla nich drogą ratunku. Podkreśla to Henryk Waniek, pisząc:

Cokolwiek podszeptują nam sentymenty, musimy to sobie powiedzieć - nic nie trwa wiecznie. Książka w dotychczasowej postaci kształciła nas, bawiła, budziła respekt przez wieki, ale obecnie wycieka przez co najmniej dwie szczeliny, powstałe w podłożu naszej kultury. Przez jedną — ku światowi nośników elektronicznych i wirtualnych; przez drugą ku czemuś, co jeszcze nazywa się książką, ale już zastrzega się, że artystyczną ${ }^{9}$.

Sztuka stała się dla książki szansą, ożywczym tchnieniem. Ten efekt działał jednak również w drugą stronę i to, przynajmniej częściowo, z podobnych względów. Daleko posunięta komercjalizacja stopniowo podważała status artysty i sens jego pracy, który coraz częściej zaczynał podlegać raczej kryteriom ekonomicznym niż twórczym. Galeriom bardziej zależało na zysku niż zapewnieniu estetycznych i intelektualnych wrażeń. Mówiąc krótko - sztuka stawała się tyleż dziedziną artystyczną, ileż handlową, co mocno akcentuje cytowany już Brogowski:

A zatem jaka jest rzeczywista i idealna postawa artysty w naszym społeczeństwie: przedsiębiorcy czy stypendysty? Fabrykanta produktów na sprzedaż czy intelektualisty? Zatrudnia go marszand czy sztuka? Pod presją ekonomiczną i ideologiczną krytyka artystyczna często ulega bożkowi handlu — którego inne formy zostały opisane i ujawnione przez Karola Marksa — a galerie, miejsca w swej istocie artystyczne, zagłębiają się w dwuznacznościach: świątynie sztuki zmieniają się w butiki, gdzie czci się kramarstwo ${ }^{10}$.

Związek z książką pomaga artystom wyrwać się z tego impasu. Z jednej strony mogą pracować na nowym dla siebie polu wyrazu, z drugiej — wyjść z opisanej dwuznaczności. Książka rozumiana jako dzieło sztuki — stworzona do oglądania, wykonana w niewielkiej liczbie egzemplarzy, często tylko w jednym, przeczy, co również podkreśla Brogowski, prawom rynku wydawniczego nastawionego na zysk i sprzedaż jak największej liczby swoich tytułów niezależnie od ich jakości i artystycznej wartości. Wyłamuje się ze wspominanych już komercjalizacji, uprzemysłowienia i związanego z nimi spowszednienia. Jednocześnie jednak cały czas pozostaje książką, a więc przedmiotem raczej do aktywnej lektury niż oglądania za wystawowymi szybami. Jej przeznaczeniem jest bycie czytaną, nawet jeśli miałoby to być czytanie rozumiane bardzo niekonwencjonalnie — polegające nie tyle na składaniu liter, ile na analizowaniu zawartych w samej strukturze

${ }^{9}$ H. Waniek, Książka?, [w:] Festiwal Książki Artystycznej ,,Wędrówka” [katalog wystawy], Warszawa 2003, strony nienumerowane.

${ }^{10}$ L. Brogowski, op. cit., s. 7. 
księgi znaków, symboli czy obrazów i to w sytuacji, gdy sama księga byłaby nią tylko z nazwy, a jej forma w niczym nie przypominałaby zszytego bloku kartek.

Wiele okoliczności sprzyjało więc mariażowi sztuki i książki i — nawet pomimo pewnych sprzeciwów ze strony zarówno bibliofilów, jak krytyków sztuki — trwa on od przeszło pół wieku, przynosząc wiele owoców. Te jednak są tak różnorodne, że w zasadzie niemożliwe do całościowego ujęcia i zdefiniowania. Dość powiedzieć, że problemy terminologiczne pojawiają się już przy próbach ustalenia ich właściwej nazwy. Liczne pomysły rozciągają się od najpopularniejszej „książki artystycznej”, przez „książkę artysty”, „obiekt książkowy” i „książkę autorską”, „książkę graficzną” i inne aż po „małą formę przestrzenną”. Każde $z$ tych haseł umocnione jest przemawiającymi za nim argumentami. Równolegle jednak wszystkie są stosunkowo łatwe do podważenia jako zbyt szerokie bądź zbyt wąskie, używające terminu „książka” do dzieła niemającego z nią (w tradycyjnym sensie) nic wspólnego, niewłaściwie stosujące przymiotnik ,artystyczny”... Kolejnych terminologicznych i klasyfikacyjnych kłopotów dostarczają wzajemne relacje artists' books z pięknymi książkami, hipertekstami, a w Polsce również prężnie rozwijającą się liberaturą. Nie powinien dziwić zatem fakt, że nazywany przez Piotra Rypsona nestorem polskiej książki artystycznej Andrzej Marian Bartczak stwierdza w jednym z esejów: „Ustalenie definicji pojęcia: książka artystyczna, jest dość kłopotliwe, choć niewykluczone"11, a artykuł Jae Jennifer Rossman poświęcony omawianym tu terminologicznym kłopotom zaczyna się od słów: „Termin artists’ books jest trudny do zdefiniowania. Debata nad jego »prawdziwą« definicją trwa od dwudziestu pięciu lat. Generalnie panuje zgoda, co do tego, że nie ma żadnej definicji”'12.

Próbując zaszczepić na polski grunt teorie zachodnich badaczy i uchwycić istotę omawianego zjawiska, Piotr Rypson pisał:

Książka artystyczna, dzieło autonomiczne - powstaje jako samodzielna praca artystyczna (np. książki W. Kamieńskiego, F. Depero, prace M. Szczuki) lub przy ścisłej współpracy artysty i literata - np. Dla Golosa Majakowskiego - Lissickiego, Europa Szczuki - Sterna, Z ponad Przybosia - Strzemińskiego. Najogólniej rzecz ujmując, artystyczne prace książkowe miały przełamywać podział na tekst (rozwijający się w czasie) i grafikę (oglądaną w przestrzeni) ${ }^{13}$.

W dalszej części swojej pracy cytowany krytyk przytaczał ustalenia Cliva Phillpota, dzielącego analizowane zagadnienie w zależności od stopnia przenikania się księgi-nośnika tekstu i sztuki na just books, bookworks i book-objects ${ }^{14}$.

11 A.M. Bartczak, Osobiste uwagi na tle powstającej Kolekcji — „Polska Książa Artystyczna z przełomu XX i XXI wieku”, Book Art Museum [strona internetowa Muzeum Książki Artystycznej w Łodzi] http://www.book.art.pl/index.php/biblioteka-ok [dostęp: 20.06.2017].

12 J.J. Rossman, The term „Artists'books”, Yale University Library [portal], http://guides. library.yale.edu/c.php?g=295819\&p=1972525 przekład autora [dostęp: 16.06.2017].

13 P. Rypson, Książki i strony. Polska książka awangardowa i artystyczna wXX wieku, Warszawa 2000, s. 11.

14 C. Phillpot, Books Bookworks Book Objects Artists’ Books, „Artforum” 1982, nr 9, s. 77. 
Pierwsze z nich znajdują się jeszcze w obszarze książki tradycyjnej i nie przynoszą nowych rozwiązań formalnych. Odznaczają się jednak swoistym napięciem powstałym między tekstem a jego graficzną oprawą. Bookworks to z kolei prace eksperymentujące z samą strukturą książki, jej wizualną formą. Book objects zaś nawiązują do samej idei książki i mają zdecydowanie swobodniejszy charakter formalny. Często jest im zdecydowanie bliżej do rzeźby czy obiektów plastycznych niż do klasycznego woluminu i tak też bywają postrzegane. Granice między tymi kategoriami są jednak płynne, a wiele dzieł nie daje się jednoznacznie przyporządkować do jednego zbioru.

Doskonałym przykładem jest tutaj liberatura dryfująca gdzieś na obrzeżach książek artystycznych. Ten zapoczątkowany przez Zenona Fajfera i Katrzynę Bazarnik ruch, zwany przez swoich twórców literaturą totalną, w dużej części swoich postulatów pokrywa się z założeniami artists’ books. Tak jak i one ma na celu przywrócenie podmiotowości księgi. Domaga się od pisarzy i wydawców patrzenia nie tylko na tekst, ale również na jego — równie istotną — fizyczną obudowę. Pomijanie tejże w procesie tworzenia dzieł literackich jest w oczach Fajfera jedną z najważniejszych przyczyn kryzysu nękającego obecnie pisarską działalność. Powiada on:

Jeśli zatem główną przyczyną kryzysu we współczesnej literaturze jest rozdźwięk między strukturą tekstu a materialną strukturą książki i utożsamienie literatury z samym tylko tekstem (niczym kartezjańskie „Myślę więc jestem” ignorujące człowieczą cielesność), to jednym sposobem jego przezwyciężenia jest ponowne zrewidowanie takich fundamentalnych pojęć jak: forma, czas i przestrzeń, dzieło literackie czy książka. Być może to właśnie panujące wciąż dogmaty paraliżują inwencję pisarzy i przyczyniają się do istniejącego stanu rzeczy ${ }^{15}$.

Żądanie zrewidowania esencjonalnych dla literatury pojęć wiąże się ściśle ze stawianiem nowych zadań przed pisarzem. Zdaniem Fajfera winien on być odpowiedzialny nie tylko za tekst, ale za książkę jako całość. W jego gestii leży przemyślenie swojego dzieła pod każdym kątem, zwracając przy tym uwagę na wszystkie fizyczne aspekty przyszłej publikacji. Całemu procesowi tworzenia musi jednak nieustannie przyświecać idea, że to tekst jest najważniejszym składnikiem dzieła, tym który warunkuje wszystkie pozostałe. „Pamiętać jednak należy, że w liberaturze wymiar tekstowy jest najważniejszy, jemu podporządkowane są wszystkie aspekty dzieła"16 — przypomina Fajfer. I ten właśnie czynnik odróżniać ma propagowany przez niego nurt od książki artystycznej. Ten pierwszy nie jest osobną dziedziną sztuki, nie wpisuje się w pełni w szeroko pojęty bookart. W myśl swoich twórców liberatura ma stanowić osobny gatunek, nurt

15 Z. Fajfer, Liberatura. Aneks do słownika terminów literackich, „Dekada Literacka” 1999, nr 5/6 (153/154), s. 8.

${ }^{16} \mathrm{Z}$. Fajfer, Jak liberatura redefiniuje ksią̇kę artystyczną. Uwagi na marginesie projektu „Kolekcja POLSKA KSIĄŻKA ARTYSTYCZNA Z PRZEŁOMU XX i XXI WIEKU”, Book Art Museum [strona internetowa Muzeum Książki Artystycznej w Łodzi], http://www.book.art.pl/index. php/biblioteka-ok [dostęp: 9.06.2017]. 
w literaturze domagający się całościowego spojrzenia na książkę jako jedność tekstu i jego wizualnej oprawy. Nie odcina się ona jednak w żadnym punkcie od swojej literackości, nie wychodzi poza jej obręb. Fajfer wyjaśnia:

Przy wszystkich powierzchownych podobieństwach fundamentalna różnica między liberaturą a książką artystyczną jest dość łatwa do uchwycenia. Do zaistnienia tej drugiej wystarczy sama książka — poddana wizji plastycznej czy konceptualnym zabiegom — tekst nie jest tu elementem wymaganym. Natomiast warunkiem niezbędnym do zaistnienia liberatury jest... literatura właśnie — tu również dziełem jest książka, jednak wszystkie jej elementy podporządkowane są słowu, ono jest elementem niezbędnym i koniecznym ${ }^{17}$.

To rozróżnienie wydaje się klarowne. Niestety traci swoją jasność przy analizie konkretnych przykładów. O ile w wypadku dużej liczby dzieł nie wystąpią klasyfikacyjne trudności, o tyle istnieje liczna grupa tych „rodzących wątpliwości” i znajdujących się na pograniczu obu dziedzin. Trafnym przykładem są prace Radosława Nowakowskiego. Kielecki pisarz niemal od początku uważany jest za przedstawiciela liberatury, jednakże gros jego dzieł z powodzeniem można zaliczyć w poczet książek artystycznych, ze sztandarową Ulica Sienkiewicza na czele. Równie kłopotliwa wydaje się klasyfikacja projektu samego Fajfera Spoglądając przez ozonowa dziurę. Jest to wydrukowany na foliale tekst umieszczony w butelce po wódce. Niewątpliwie dużo bliżej mu do księgarskich eksperymentów wykonywanych przez plastyków czy rzeźbiarzy niż do tradycyjnej księgi, a może nawet także liberatury. Fajfer broni swojego dzieła, pisząc, że jego istotę stanowi ukryty w naczyniu tekst, a więc należy ono do literatury. Wydaje się jednak, że rzecz jest znacznie bardziej skomplikowana...

Nie wdając się w dalsze dyskusje na temat statusu liberatury, która nie jest zasadniczym przedmiotem niniejszego tekstu, wystarczy powiedzieć, że doskonale unaocznia ona charakterystyczną dla książek artystycznych płynność granic i pewną niedookreśloność. Jako dzieło czerpiące z wielu różnych szkół, tradycji i sztuk artists' book doskonale wpisuje się w stworzony przez Dicka Higginsa termin , intermedium”, w którym:

[...] element wizualny / obraz / jest pojęciowo stopiony ze słowami. Może to być abstrakcyjna kaligrafia, poezja konkretna, ,poezja wizualna” / nie chodzi tu o jakikolwiek wiersz z mocnym akcentem wizualnym; termin ten jest czasem używany do dzieł plastycznych, w których występuje wiersz, często jako fotografia, lub w którym fotograficzny materiał plastyczny prezentowany jest jako sekwencja rządzona swoją własną gramatyką, tak aby każdy element wizualny był słowem w zdaniu $[\ldots]^{18}$.

Mamy tu zatem do czynienia z dziełem czerpiącym z doświadczeń wielu dziedzin sztuki, w żaden sposób nieskrępowanym więzami danej szkoły czy nurtu. Widać w nim tendencje do łączenia różnych środków wyrazu i przekraczania kolejnych granic, co ma na celu osiągnięcie pełniejszego efektu artystycznego.

17 Ibidem.

${ }^{18}$ D. Higgins, Intermedia i inne eseje, przeł. M. i T. Zielińscy, red. P. Rypson, Warszawa 1985, s. 21. 
Jest to praca odwołująca się do licznych tradycji, poszukująca oryginalnych rozwiązań. Przelatująca ponad podziałami, a raczej przepływająca przez nie. Dzieło intermedialne to dzieło płynne, dokładnie tak, jak nasza rzeczywistość. Książka artystyczna ze względu na swoją różnorodność i mnogość formalnych rozwiązań wydaje się doskonale wpisywać w tę definicję.

Niestety owa rozmaitość artists' books jest równocześnie powodem związanych z nimi terminologicznych problemów i licznych sporów, a także oporów, między innymi ze strony środowisk bibliofilskich, pojmujących książkę w skostniały sposób. Powiada Grzegorz Matuszak, wspominając swoje wystąpienie sprzed przeszło trzydziestu lat:

Bibliofilstwo współczesne choruje na to, że w dużej mierze jest domeną ludzi o konwencjonalnym smaku, wyrosłym na pseudoklasycznej manierze schyłku XIX wieku, zarówno w treści, jak i formie, co nader wyraźnie widoczne jest choćby w wielu współczesnych publikacjach bibliofilskich. Czas się przecież nie zatrzymał, a tylko bibliofile zabrnęli w matecznik i nie potrafią z niego wyjść. Zdumiewa, jak trudno współczesnemu bibliofilowi, osobliwie w jego inicjatywach wydawniczych, spotkać się ze współczesnym artystą książki, wypowiadającym się językiem sztuki XX wieku. [...] Myślę, że ta surowa diagnoza niewiele straciła na aktualności, mimo że postawiona została prawie ćwierć wieku temu ${ }^{19}$.

Mimo upływu czasu sytuacja rzeczywiście niewiele się zmieniła. Winna jest temu postawa wielu bibliofilów, ale także — zdaniem Matuszaka — współczesna sztuka, coraz częściej epatująca tandetą i kiczem. Ta, w jego opinii, nader często odznacza się błazenadą, bufonadą, a wręcz bełkotliwością i formalną tandetą. Przez to, że drwi z wartości, które konstytuowały ją przez wieki, nadając jej elitarny charakter, wynosi do rangi dzieł prace kiczowate, nieraz skomercjalizowane. Pozwala, by sztuką mogło się stać absolutnie wszystko. Jak stwierdza Matuszak, pracę wielu współczesnych twórców, także tych związanych z książką, ze względu na ich bezmyślność i niechlujstwo należałoby skwitować parafrazą cytatu z Biblii: „Panie, odpuść im, bo nie wiedzą, co czynią" ${ }^{20}$. Stanowiska współczesnych artystów i bibliofilów są zbyt od siebie oddalone. Jedno zamyka się na drugie i odwrotnie. Powodów takiego stanu rzeczy jest oczywiście wiele — od bariery pokoleniowej, przez brak obiektywnych kryteriów do oceny dzisiejszej sztuki, aż po tak prozaiczne zjawisko, jak deficyt dobrej woli z obydwu stron. Tę część swoich rozważań Matuszak podsumowuje następująco:

Między środowiskiem najbardziej predestynowanym do odbioru książki artystycznej, a środowiskiem twórców takich książek brakuje płaszczyzny porozumienia, wzajemnego otwarcia i dialogu na temat, w jakiej mierze współczesna książka artystyczna może sprostać oczekiwaniom bibliofilów na piękną książkę ${ }^{21}$.

${ }^{19}$ G. Matuszak, Impresje bibliofila na temat książki artystycznej, Book Art Museum [strona internetowa Muzeum Książki Artystycznej w Łodzi], http://www.book.art.pl/index.php/biblioteka-ok [dostęp: 8.06.2017].

${ }^{20}$ Właściwe brzmienie cytatu to „Ojcze, przebacz im, bo nie wiedzą, co czynią” (Łk 23, 34).

${ }^{21}$ G. Matuszak, op. cit. 
W dalszej części swojego eseju Matuszak skupia się na kolekcji Polska Książka Artystyczna przełomu XX $i$ XXI wieku i choć, jak na przyjęte przez siebie stanowisko bibliofila, jest on stosunkowo otwarty na nowe tendencje w sztuce, to jednak podkreśla, że nie może zgodzić się na wiele przyjętych przez inicjatorów kolekcji założeń. Przede wszystkim nie podoba mu się określanie terminem „księga" rzeczy, które bynajmniej nią nie są, a nawet jej nie przypominają. Podkreśla, że książka to graficzny dokument, zazwyczaj w formie kodeksu, który utrwala i przekazuje ludzką myśl. Nie godzi się więc na określanie tym mianem unikatowych dzieł, będących, na przykład, kamiennymi czy drewnianymi rzeźbami lub też instalacjami. Co więcej, krytykuje również nazywanie ich „obiektami”. Matuszak stwierdza:

Tego rodzaju konceptualne pomysły, znane mi z autopsji, zawłaszczają nazwę książka i uzurpują sobie bycie czymś, czym w żadnym wypadku nie są. W praktyce funkcjonuje termin „obiekty książkowe”, który też uważam za nietrafiony. Można oczywiście tworzyć tego rodzaju „obiekty”, nawet je zbierać, ale upominam się o zachowanie pewnej czystości terminologicznej i potrzebę znalezienia dla nich odrębnej nazwy, może na przykład - małe formy przestrzenne. Nie należy nazywać książką tego, co książką ex definitione nie jest. W kolekcji książki artystycznej, jeśli do niej takie „obiekty” trafią, powinny, moim zdaniem, być wyraźnie wyodrębnione jako twory powstające na obrzeżach i jako udające książki nie mogą należeć do podstawowego składu kolekcji ${ }^{22}$.

Matuszak wymaga, by książką nazywane było to, co ma jej formę, czy to kodeksową, czy którąś z jej starszych realizacji. Nie ma do tego określenia prawa dzieło nawiązujące do niej jedynie ideologicznie czy symbolicznie. Cytując Alberta Camusa, autor przytaczanego eseju twierdzi, że błędne nazywanie rzeczy dodaje nieszczęścia światu. Oczywiście Matuszak zdaje sobie sprawę, że takie przedstawienie problemu jest pewnym nadużyciem, równolegle jednak uważa, że przez mieszanie pojęć, wprowadzanie chaosu terminologicznego oraz uzurpowanie przez artystów niewłaściwych określeń dla ich dzieł prowadzi do dezorientacji i zagubienia, a w ostateczności zniechęcenia odbiorcy do sztuki współczesnej. I w tym sensie jest to nieszczęście, którego przyczyną są ludzie nieprzykładający odpowiedniej wagi do prawidłowego nazywania rzeczy. Chcąc jeszcze dobitniej podkreślić swoje stanowisko, Matuszak kończy rozważania parafrazą wiersza Juliana Tuwima: ,a nade wszystko słowom naszym, chytrze zmienionym przez krętaczy / jedyność przywróć i prawdziwość... niech „książka” zawsze książkę znaczy, także tę, która ma ambicje być artystycznie uformowana"23.

Bibliofile, mówiąc krótko, poszukują pięknej książki, a ta, choć rodzi się ze związku sztuk pięknych z książką, nie jest jeszcze „artystyczna”. Jak konstatuje Rafał Solewski:

Dla pełnego obrazu rozważanego zjawiska należy zauważyć fenomen livre d'artiste. Jego tradycję stanowią iluminowane inkunabuły czy drogocenne wydania ksiąg z epoki druku. Jed-

${ }^{22}$ Ibidem.

${ }^{23}$ Ibidem. 
nak samą nazwę stosuje się wobec ekskluzywnych publikacji wydawanych głównie w środowisku paryskim początku XX stulecia, łączących literaturę (zwykle twórczość młodych poetów) z najczęściej kubistyczną grafiką, gdzie ilustracje organicznie korespondowały z tekstem [...]. Jednak sama eskalacja funkcji estetycznej ilustracji i oprawy, przy wciąż dominującej estetycznie roli organizacji tekstu, nie jest cechą, która wyznaczałaby interesującą nas tematykę, odróżniającą się od funkcjonowania tradycyjnej książki. Prace zdobniczo-dekoracyjne $i$ livre d'artiste wskazują natomiast na świadomość artystów, że czynniki literackie związane ze zwerbalizowanym i zapisanym komunikatem mogą współgrać $\mathrm{z}$ estetyką wizualną, choć mogą jej też zupełnie ustępować. To okaże się zresztą najłatwiej postrzegalną cechą książki artystycznej24.

W tym miejscu wyraźnie uwidacznia się jeden z elementów derywacyjnych książki artystycznej, który pośrednio był już wspominany — jej stosunek do tekstu. W tego typu dziełach słowo pisane nie jest już składnikiem konstytuującym całość projektu, często bywa wręcz zbędne. Bez większych kłopotów uda nam się znaleźć prace, które ograniczają jego rolę do absolutnego minimum, a wręcz rugują je poza swój obręb. Skupiają się raczej na samej idei i tradycji związanej z księgą, jako wyjątkowym przedmiotem, a nie wyłącznie nośnikiem tekstu, co dobitnie podkreślał Dick Higgins, pisząc, że w przypadku artists' books obcujemy $\mathrm{z}$ „książką zrobioną dla niej samej, nie zaś dla informacji, którą zawiera” ${ }^{25}$. W te słowa doskonale wpisuje się Biblioteka Jarosława Kozłowskiego, którą można określić jako manifest podmiotowości księgi. Składają się na nią tworzące swoistą kolumnę, ułożone na sobie od podłogi do sufitu kodeksy, które zostały pomalowane przez artystę białą emulsyjną farbą. Żadnego z nich nie można było ani przeczytać, ani nawet wyjąć, gdyż groziłoby to zawaleniem się całej konstrukcji. Odbiorca został odcięty od ich zawartości — tekstu. Nie miał żadnej możliwości, by się do niego dostać. Mimo to, tworzące kolumnę przedmioty nie przestały być postrzegane jako książki. Dzięki zasłonięciu przed oglądającymi, ich wnętrza mogły zaistnieć jako autonomiczne obiekty. Inną próbą wyjścia ze stereotypowego myślenia o księdze były Acustic Books Joanny Adamczewskiej, zwracające uwagę na dźwiękowe właściwości kodeksów. Projekt ten artystka zaczęła w drugiej połowie lat osiemdziesiątych. W jego ramach z różnorodnych typów papieru o różnej powierzchni i gramaturze, kleju, kopert pocztowych, kalk, ale także drobnych plastikowych przedmiotów, piasku, mąki ziemniaczanej, soli, igieł, taśm klejących stworzyła serię książek do słuchania. Każda z nich została opatrzona tytułem związanym z terminologią muzyczną (W poszukiwaniu linii melodycznej, Repetycja, Continuo), a materiały, z jakich ją wykonano, miały pomóc w osiągnięciu właściwego efektu głosowego, konkretnej tonacji muzycznej. Poprzez dotyk dzieła te wydają z siebie dźwięki, zupełnie przełamując obecny w naszej kulturze stereotyp książki jako obiektu, który powinno się poznawać w ciszy. Te woluminy przemawiają odgłosem przewracanych stron, rwanych kartek, taśmy odklejanej

${ }^{24}$ R. Solewski, Metaksiążka. Ksią̇ka artystyczna jako hermeneutyka księgi, „Estetyka i Krytyka” 2005, nr 7-8, s. 123-124, http://estetykaikrytyka.pl/art/7-8/eik_7-8_10.pdf [dostęp: 19.06.2017].

${ }^{25}$ D. Higgins, A preface, [w:] Artists'Books. A Critical Anthology and Sourcebook, red. J. Lyons, Rochester 1985, s. 11. 
od papieru, otwieranych kopert. Nawet więc wśród polskich artists' books, które wydają się mocno zrośnięte $\mathrm{z}$ tekstem, podobne przykłady moglibyśmy mnożyć bardzo długo.

Rozluźnienie związku ze słowem pisanym jest zatem jedną z istotniejszych cech omawianego zjawiska. Podobnie jak przywoływane wcześniej: bunt przeciw komercjalizacji zarówno książki, jak i sztuki czy swoista artystyczna wolność wyrywająca obie te dziedziny z kolein, w których wydawały się utkwić na wieki wieków. Nie mniej ważne wydają się unikatowość oraz konceptualizm. Artists' books przekształcają księgę-nośnik treści $\mathrm{w}$ dzieło sztuki, a w tym niezwykle istotna jest przecież forma. Czyniąc to, jednocześnie podejmują pogłębioną refleksję nad całą narosłą wokół niej tradycją. Powiada Solewski:

Samo wybranie i zaprezentowanie formy książki nabrało cech komunikatu znaczeniowego. Poznaliśmy już książkę postrzeganą po prostu jako jedno z mediów. Jednak książka — przez wybór trudniejszej i bardziej wyrafinowanej formy komunikacji oraz rozrywki — zaczyna też sygnalizować szlachetną staroświeckość, trochę ekstrawagancję, elitarność i snobizm. Choć, patrząc z innej strony, oznacza też zacofanie i ubóstwo - brak telewizora, komputera, Internetu... Wreszcie książka, a w niej opisane już różnorodne doświadczenia z pismem i tekstem, to także gra zwracająca uwagę na proces komunikacji. Wybór książki i eksperymentowanie z jej formą — jakże ważne akty w tworzeniu książki artystycznej — budzą zatem refleksję o roli społecznej książki, o funkcji przekazywania informacji i o sposobie spełniania owej funkcji ${ }^{26}$.

Takie spojrzenie znacznie poszerza obszar zainteresowania twórców zajmujących się artists' books. Ich praca okazuje się refleksją nie tylko nad księgą, ale także jej funkcjami społecznymi i poczesnym miejscem, jakie zajmuje w kulturze. Biorąc pod uwagę fakt, jak istotny element naszej cywilizacji stanowi książka a jest przecież jednym z jej fundamentów — łatwo dojść do wniosku, że mamy do czynienia z wypowiedziami na temat całej naszej rzeczywistości. Taka konstatacja jednak w żaden sposób nie przybliża nas do uchwycenia tego, czym jest książka artystyczna. Wręcz przeciwnie — podkreślając jej niczym nieskrępowaną swobodę twórczą, jednocześnie gwałtownie rozszerza obszar jej zainteresowań. To już nie tylko komentarz w dyskusji nad istotą księgi, próba ucieczki na nowe, twórczo inspirujące obszary czy bunt przeciw komercjalizacji, a coś znacznie więcej — jak pisze Solewski - metaksiążka:

Tak zatem pozbawianie definicji książki jej elementów w dziele nazywanym książką artystyczną służy refleksji o fenomenologicznej istocie książki. Książka artystyczna okazuje się metaksiążką, hermeneutyczną interpretacją głębokiej istoty księgi, zaś artysta, oprócz swej intuicyjne często spełnianej misji wywoływania piękna, staje się — też intuicyjnie — wyjaśniającym, tłumaczącym i poszukującym prawdy oraz piękna filozofem ${ }^{27}$.

Te wnioski zdają się zbyt daleko idące, a sama rola książki artystycznej przeceniana. Trzeba wszak pamiętać, że to ciągle stosunkowo niszowe zjawisko, szukające swojej autonomii gdzieś pomiędzy granicami dwóch różnych dziedzin

${ }^{26}$ R. Solewski, op. cit., s. 140.

27 Ibidem, s. 143. 
sztuki, a jego konkretne realizacje, choć — oczywiście — igrają z formą księgi, nawiązują także do wielu innych spraw i dziedzin. Znajdziemy przecież niemało artists' books odwołujących się choćby do literatury. Sam jednak fakt przetwarzania i reinterpretowania dzieł pisarzy nie sprawia, że są metaliterackie. Spoglądając na problem z drugiej strony, moglibyśmy też spytać, czy powieści, wiersze i dramaty nawiązujące do toposu księgi, przydające jej nowych kontekstów, rozszerzające pole semantyczne, budujące bądź atakujące związaną z nią tradycję, to już metaksiążki. W końcu, jak pisał ceniony artysta Andrzej Marian Bartczak:

Przecież każda książka jest potencjalnie artystycznym obiektem. Typowa, jeśli można tak powiedzieć, książka literacka czy beletrystyczny przekaz i nośnik tekstu, jakże często jest poruszającym emocje, wyobraźnię i intelekt duchowym przeżyciem ${ }^{28}$.

\section{$\mathrm{W}$ innym miejscu retorycznie pytał:}

Czy Mickiewicz, Norwid, Słowacki, Miłosz, Herbert, ks. Twardowski, Różewicz, Iwaszkiewicz i wielu innych, czy oni nie są twórcami książek i wielkimi artystami? [...] Wszyscy oni, choć nie malarze, graficy czy rzeźbiarze, są przecież także artystami książki ${ }^{29}$.

Rzecz w tym, że — nad czym ubolewam — czasy wielkich narracji i projektów, jeśli jeszcze się nie zakończyły, to chylą się ku upadkowi. Książka artystyczna nie stanowi tego typu opowieści. Przeciwnie — jest skutkiem jej rozpadu, pękania granic, zderzeń odłamków, fragmentów, ułamków, które umożliwiły spotkanie się księgi i sztuki. Mam wrażenie, że wpisywanie jej w porządek meta- , przyrównywanie artysty do poszukującego prawdy i piękna filozofa jest historią z poprzedniej epoki. To po prostu zbyt panoramiczna i jednoznaczna perspektywa. Dziś już nieautentyczna. Trzeba przyznać rację Jeanowi-François Lyotardowi, który oceniał:

We współczesnym społeczeństwie i we współczesnej kulturze, w społeczeństwie postindustrialnym, w kulturze ponowoczesnej, pytanie o prawomocność przyjmuje inną postać. Wielka opowieść, niezależnie od sposobu, w jaki dokonuje unifikacji wiedzy, to znaczy niezależnie od tego, czy jest opowieścią spekulatywną, czy emancypacyjną, straciła wiarygodność ${ }^{30}$.

Dlatego książkę artystyczną postrzegałbym raczej jako małą opowieść, zbiór wielu małych opowieści. Ciąg rozmaitych historii o księdze, sztuce, ich wzajemnej relacji i wszystkim, co się z tym wiąże, a więc ich społecznej roli, funkcji, tradycji. Nie byłyby to wielkie dziewiętnastowieczne narracje, a współczesne nowele, aspirujące już nie do wyjaśnienia natury całego świata, lecz jego niewielkiego wycinka. Zadowalają się uchyleniem rąbka tajemnicy, nie muszą od razu zrywać zasłony. Panoramę zastępuje w nich ujęcie lokalne, zmiana perspektywy, spojrzenie na dany problem pod innym kątem i ujrzenie go w nowym świetle. Książki

28 A.M. Bartczak, op. cit.

${ }^{29}$ Ibidem.

${ }^{30}$ J.-F. Lyotard, Kondycja ponowoczesna. Raport o stanie wiedzy, przeł. M. Kowalska, J. Migasiński, Warszawa 1997, s. 111. 
artystyczne, mądrzejsze o lekcję modernizmu, nie dążą do jednolitego projektu, który w końcu zaprowadzi wieczny, idealny ład. Wiedzą już, że to niemożliwe. Zamiast tego proponują wiele rozmaitych, skromnych narracji zgromadzonych pod wspólnym szyldem — szerokim i niejednoznacznym, to prawda, ale równocześnie nikogo nie wykluczającym. I tak chyba powinno pozostać.

W pełni zrozumiałe są również głosy krytyczne, mówiące choćby o tym, że w zasadzie sami nie wiemy, z czym mamy do czynienia, że nie są to już książki, ale przecież też nie rzeźby czy obrazy, że ów zbiór jest zbyt szeroki, że to raczej pole do badań dla krytyków sztuki niż literaturoznawców czy bibliologów... Mają one swoje oczywiste uzasadnienie. Wynika ono jednak po raz kolejny ze spoglądania na problem z perspektywy czasów wielkich opowieści: o księdze, sztuce i innych ważkich sprawach. Wystarczy jednak spojrzeć na problem książki artystycznej i książki w ogóle pod kątem, jaki proponował Krzysztof Migoń — przez pryzmat „kultury książki”:

Użyteczność pojęcia „kultura książki” dla określenia przedmiotu i charakteru bibliologii bierze się stąd, że może ono pomieścić w sobie i skoncentrować wszystkie materialne i duchowe aspekty książki i świata książek. Objaśnia książkę pojedynczą i zbiory książek (cały nakład, repertuar wydawniczy, asortyment księgarski, całe uniwersum książek) jako wytwory kultury materialnej, technicznej i duchowej, bo w pierwszym rzędzie kulturę książki danej epoki i środowiska determinują materiały piśmienne i narzędzia, techniki drukarskie, zdobnicze i introligatorskie. Na tej podstawie, dzięki funkcjonalnej syntezie tego, co w książce materialne (fizyczne) i tego, co treściowe, funkcjonuje ona jako narzędzie utrwalania tekstów i instrument komunikacji ${ }^{31}$.

I w to pojęcie właśnie wpisywałbym artists' books. Być może często nie są one książkami w wąskim tego słowa znaczeniu, na pewno jednak wchodzą w obręb ich kultury. Dlatego też, rezygnując z mających zamknąć omawiane zjawisko w sztywne ramy i ograniczających tak istotną dla niego wolność wypowiedzi terminologicznych oraz klasyfikacyjnych obostrzeń, pozostawiając jałowe spory na temat tego, co już jest artists' books, a co jeszcze nie, zaproponowałbym inne podejście do problemu: odrzucenie akademickich rygorów na rzecz postawy krytyka nieskrępowanego wymogami danej szkoły, dyscypliny czy tradycji, dopasowującego raczej narzędzia do konkretnego dzieła niż odwrotnie. Eklektyka podążającego za tym zjawiskiem i wnikliwie je obserwującego. Analizującego, lecz bez zbędnego naruszania jego i tak nadwątlonej autonomii. Najważniejsza nie jest przecież często sztuczna typologizacja, wytyczanie i tak niepasujących tu granic, lecz wnikliwa, złożona lektura tych małych opowieści o kulturze książki. Nawet jeśli nie ma w nich ani jednej litery, to nie brakuje inspirującej i ożywczej treści czekającej na obdarzonego odpowiednią wrażliwością badacza-czytelnika. Stawianie murów wokół zjawiska, którego esencję stanowi ich przekraczanie, mija się z celem.

${ }^{31}$ K. Migoń, Bibliologia - nauka o kulturze książki, ,Nauka” 2005, nr 2, s. 53-54. 


\section{Bibliografia}

Bartczak A.M., Osobiste uwagi na tle powstającej Kolekcji — „Polska Książa Artystyczna z przetomu XX i XXI wieku”, Book Art Museum [strona internetowa Muzeum Książki Artystycznej w Łodzi], http://www.book.art.pl/index.php/biblioteka-ok [dostęp: 20.06.2017].

Bauman Z., 44 listy ze świata płynnej nowoczesności, przeł. T. Kunz, Kraków 2011.

Brogowski L., L'art, le livre, meme combat, [w:] Livres imprimés et maquettes. Les Éditions Incetain Sens [katalog wystawy], http://www.hermandevries.org/arch_catalogues/cat_2003_bn_livres.pdf [dostęp: 14.06.2017].

Fajfer Z., Jak liberatura redefiniuje ksiązę artystyczną. Uwagi na marginesie projektu „Kolekcja POLSKA KSIAZŻKA ARTYSTYCZNA Z PRZEŁOMU XX i XXI WIEKU”, Book Art Museum [strona internetowa Muzeum Książki Artystycznej w Łodzi], http://www.book.art.pl/index. php/biblioteka-ok [dostęp: 9.06.2017].

Fajfer Z., Liberatura. Aneks do stownika terminów literackich, „Dekada Literacka” 1999, nr 5/6 $(153 / 154)$.

Higgins D., Intermedia i inne eseje, przeł. M. i T. Zielińscy, red. P. Rypson, Warszawa 1985.

Higgins, A preface, [w:] Artists'Books. A Critical Anthology and Sourcebook, red. J. Lyons, Rochester 1985.

http://www.hermandevries.org/arch_catalogues/cat_2003_bn_livres.pdf [dostęp: 14.06.2017].

Kępińska A., Sztuka w kulturze płynności, Poznań 2003.

Książka artystyczna jako obiekt oraz warsztat edukacyjny, red. E. Józefowski, Zielona Góra 1998.

Lyotard J.-F., Kondycja ponowoczesna. Raport o stanie wiedzy, przeł. M. Kowalska, J. Migasiński, Warszawa 1997.

Matuszak G., Impresje bibliofila na temat ksiązki artystycznej, Book Art Museum [strona internetowa Muzeum Książki Artystycznej w Łodzi], http://www.book.art.pl/index.php/biblioteka-ok [dostęp: 8.06.2017].

Migoń K., Bibliologia - nauka o kulturze książki, „Nauka” 2005, nr 2.

Nowakowski R., Czy istnieje hipertekstowa ksiązka (artystyczna), Book Art Museum [strona internetowa Muzeum Książki Artystycznej w Łodzi], http://www.book.art.pl/index.php/biblioteka-ok [dostęp: 6.06.2017].

Phillpot C., Books Bookworks Book Objects Artists’Books, „Artforum” 1982, nr 9.

Rossman J.J., The term „Artists 'books”, Yale University Library [portal], http://guides.library.yale. edu/c.php?g=295819\&p=1972525 [dostęp: 16.06.2017].

Rypson P., Książki i strony. Polska książka awangardowa i artystyczna w XX wieku, Warszawa 2000.

Solewski R., Metaksiążka. Książka artystyczna jako hermeneutyka księgi, „Estetyka i Krytyka” 2005, nr 7-8, http://estetykaikrytyka.pl/art/7-8/eik_7-8_10.pdf [dostęp: 19.06.2017].

Waniek H., Książka?, [w:] Festiwal Ksiązki Artystycznej ,,Wędrówka” [katalog wystawy], Warszawa 2003.

\section{Artists' books, or what is the fruit of the marriage of a book with art}

Summary

This text is an attempt to looking at the status of artists' books — interesting phenomenon, which blends worlds of book and art. It includes the opinions of art critics, bibliophiles, publishers, creators of literature and artists. History of the artists' books and external conditions, which have an influence on its birth were briefly outlined. Image of this phenomenon turns out indeterminate and 
internally contradictory. Theories, typologies, attempts to define or even fix the right term are often mutually exclusive. This situation raises questions about their legitimacy. Maybe we should accept the fact that certain indeterminacy and impossibility to enclose in rigid frames is an inherent feature of artists' books because otherwise they would lose their diverse and open character.

KEYWORDS: artists' books, literature, artbook, book art 